\title{
Akılcı İlaç Kullanımı Dersinin Ön Lisans Eğitimindeki Önemi
}

\author{
The Importance of the Rational Drug Use Lesson in the Education of Associate Degree
}

\author{
Merve SAYGI BACANAK
}

ÖZ

İlaçların gereksiz ve yanlış kullanımı ciddi sağlık sorunlarına ve tedavi maliyetlerinin artmasına neden olmaktadır. Dünya Sağlık Örgütü’nün başlatmış olduğu "Akılcı İlaç Kullanımı” çalışmaları tüm dünyada hızla yaygınlaşmaktadır. Bu çalışmaların amacı doğru ilacın doğru hastada, doğru zamanda, doğru dozda, doğru süreyle ve doğru uygulama yolu ile uygulanmasının sağlanmasıdır. Akılcı İlaç Kullanımının doktor, eczacı ve hemşirelerde olduğu gibi, sağlık teknisyenleri dâhil tüm sağlık çalışanlarının eğitim programlarında yer alması bahsi geçen meslek gruplarının da Akılcı İlaç Kullanımı konusunda yeterli bilgi sahibi olarak ve Akılcı İlaç Kullanımının önemine vakıf olarak mezun olması son derece önemlidir.

Anahtar Kelimeler: Akılcı ilaç kullanımı, ön lisans eğitimi, eğitim

\begin{abstract}
Irrational and incorrect use of drugs cause serious health problems and increased treatment costs. Rational Drug Use trainings initiated by the World Health Organization are spreading rapidly all over the world. The aim of these trainings is to ensure the right drug to be administered to the right patient, at the right time, with the right dose, with the right period and with the right route. It is extremely important to include the Rational Drug Use to the education of all health workers including health technicians as well as doctors, pharmacists and nurses for making the mentioned occupational grup to have enough knowledge about and to be competent on Rational Drug Use when they are graduated.
\end{abstract}

Keywords: Rational drug use, education of associate degree, education

İlaçların gereksiz ve yanlış kullanımı, hastalık ve ölüm oranlarında artış, istenmeyen etkilerin artması, kaynakların yanlış tüketilmesi nedeniyle temel ilaçlara bile ulaşılabilirliğin azalması, acil ve temel ilaçlara karşı direnç gelişmesi, tedavinin ekonomik ve sosyal maliyetinin artması gibi sorunlara neden olmaktadır (1). Bu nedenlerden dolay1 çeşitli çözüm yolları geliştirilmeye çalışılmış ve dünyada “Akılcı İlaç Kullanımı (AİK)” çalışmaları başlatılmıştır (1). Dünya Sağlık Örgütü (DSÖ)'nün 1985 yılında Nairobi’de yapmış olduğu toplantı AİK çalışmaları için bir başlangıç olarak kabul edilmektedir (2). AİK, DSÖ tarafindan; kişinin hastalığına ve bireysel özelliklerine göre uygun olan ilaca, uygun süre ve dozda, en uygun maliyette ve kolayca ulaşabilmeleri olarak tanımlanmıştır (2). AİK çalışmalarının temel amacı, ilaçların etkili ve güvenli kullanılmasının sağlanması, hastaya en uygun ilacın en iyi maliyetle sunulmasidir. 
DSÖ’nün tahminlerine göre, ilaçların \% 50'sinden fazlası uygun olmayan şekilde reçetelenmekte, temin edilmekte veya satılmaktadır (3). Tüm hastaların yarısı da ilaçlarını doğru şekilde kullanamamaktadır (3). İlaçlar doğru kullanılmaz ise çeşitli sorunlara yol açabilirler. Modern toksikolojinin kurucusu olarak kabul edilen İsviçre'li bilim insanı Paracelsus'un "her madde zehirdir, zehir olmayan madde yoktur; zehir ile ilacı ayıran dozdur" sözünde de vurgulandığı gibi uygun dozda ilaç uygulanması büyük önem taşımaktadır. Eksik miktarda ilaç alınması tedavi sağlamazken, fazla miktarda ilaç alınması ise zararlı etkilere neden olabilmektedir. İlaçların hangi yoldan ve nasıl uygulanacağı kişinin fiziksel ve zihinsel gelişimine, hastalığına, hastalığının şiddetine ve kullanılacak ilaca göre farklılık gösterebilir. İlaçların etkileri bebek, çocuk, ergen ve yaşlılarda, eşlik eden hastalıkların varlığında, başka ilaçlarla beraber kullanımlarda, bitkisel ürünlerle veya destek ürünleri ile birlikte kullanımlarda ve bazı yiyeceklerin birlikte tüketilmesi ile değişebilmektedir. Gebelik ve emzirme dönemleri veya ilaç alerjileri gibi durumlarda her ilaç kullanılamamaktadır. Doğru ilacın doğru hastada, doğru zamanda, doğru dozda, doğru süreyle ve doğru uygulama yolu ile uygulanması büyük önem taşımaktadır.

AİK çalışmaları kapsamında ülkemizde bu konuda bilinç oluşturabilmek için Türkiye İlaç ve Tıbbi Cihaz Kurumu bir eylem planı yayınlamış ve tüm sağlık çalışanlarının eğitim programlarına AİK dersinin eklenmesinin gerekli olduğunu belirtmiştir (4). AİK konusunda sadece doktorların, eczacıların veya hemşirelerin değil, ilacı uygulayan diğer tüm sağlık çalışanlarının da önemli görevleri vardır. Ülkemizdeki sağlık teknisyenlerinin görev ve sorumlulukları tanımlanmıştır. Hastanelerin acil servis bölümlerinde ve ambulanslarda istihdam edilen acil tıp teknikerleri ve teknisyenleri, intravenöz ve intraosseöz girişim ile hastaneye ulaşıncaya kadar Sağlık Bakanlığınca belirlenen acil ilaçları uygularlar (5). Acil ilaçları uygulamadan önce tıbbi danışmandan onay alırlar (6). Kardiyo-pulmoner resusitasyon ve defibrilasyon uygulamaları esnasında tıbbi danışman olan hekimin onayı olmadan ilaç uygulamaya yetkilidirler (6). Ameliyathane, acil servis, reanimasyon servisi ve ağrı odalarında ve tüp bebek merkezlerinde görev alabilen anestezi teknisyenleri/teknikerleri, anestezi uzmanı veya onun bulunmadığı hallerde ameliyathane sorumlu uzmanının sorumluluğu altında, bunların ve ameliyatı yapan uzmanın direktiflerine göre ameliyatın ve narkozun salimen ve rahat bir şekilde sonuçlanması için gerekenleri yaparlar (5). Uygulanacak anestezi yöntemine göre gerekli ilaçları hazırlarlar (5). Anestezinin güvenli bir şekilde uygulanabilmesinde, sürdürülebilmesinde ve sonlandırılmasında uzman doktora yardımcı olurlar (5). Hastaya ve anestezi işlemine ilişkin kayıtları tutar ve uzman doktoru bilgilendirirler (5). Hastaneler, tıp merkezleri ve görüntüleme merkezlerinin radyoloji, nükleer tıp ve radyoterapi bölümlerinde çalışabilen tıbbi görüntüleme teknisyenleri/teknikerleri hekim eşliğinde hastaya radyoopak madde enjeksiyonu yapar, radyografik inceleme öncesi hastayı hazırlar ve bilgilendirirler (5). Radyoterapi teknikeri, uzman doktorun belirlemiş olduğu tedaviyi hastaya uygular, tedavi sırasında hastayı izler ve beklenmeyen bir durum veya komplikasyon durumunda doktoru bilgilendirir (5). Görüldügü gibi acil durumlarda ve gerektiğinde ilaç uygulama yetkileri bulunan bu meslek gruplarının, uygulanacak ilaçlar hakkındaki bilgiyi ve talimatları hekimden doğru alması, hastaya veya hekime gerektiğinde ilaç ile ilgili bilgiyi doğru aktarması, doğru ilaç uygulaması yapması ve gerektiğinde hekimi uyarması ve bilgilendirmesi açısından AİK eğitimi önemlidir. Ayrıca hamilelik, emzirme dönemi, çocuklar, yaşlılar, böbrek yetersizliği, karaciğer yetersizliği, ilaç alerjisi öyküsü, kullanılan diğer ilaç, bitkisel veya destek ürünler gibi özel durumların hekime bildirilmesi bakımından da hasta ile doğrudan iletişim halinde olan bu meslek gruplarında AİK bilincinin artırılması gereklidir.

Akılcı olmayan ilaç kullanımı, hastaların tedaviye uyumunun azalmasına, ilaç etkileşimlerine, bazı ilaçlara karşı direnç gelişmesine, hastalıkların tekrarlamasına ya da uzamasına, istenmeyen olay görülme sıklığının artmasına, tedavi maliyetlerinin artmasına neden olmaktadır. Doktor, eczacı ve hemşirelerde olduğu gibi, sağlık teknisyenleri dâhil tüm sağlık çalışanlarına AİK eğitimi verilmesinin faydalı ve gerekli olduğu ve teşvik edilmesi gerektiği DSÖ tarafindan bildirilmiştir (7).

Sonuç olarak değinilen hususlar göz önünde bulundurulduğunda, AİK'nın, ön lisans düzeyinde eğitim vererek acil tıp teknisyeni/teknikeri, anestezi teknisyeni/ teknikeri ve tıbbi görüntüleme teknisyeni/teknikeri yetiştiren üniversitelerin ilgili bölümlerinin eğitim programlarında yer alması ve bahsi geçen meslek gruplarının AİK konusunda yeterli bilgi sahibi olarak ve AİK'nın önemine vakıf olarak mezun olmaları son derece önemlidir. 


\section{KAYNAKLAR}

1. http://www.akilciilac.gov.tr/ [Erişim tarihi: 17.12.2017]

2. Conference of Experts on the Rational Use of Drugs, World Health Organization, Nairobi, Kenya, WHO/CONRAD/ WP/RI, 25-29.11.1985. PDF Dokümanı [Erişim tarihi: 17.12.2017]

3. http://www.who.int/medicines/areas/rational_use/en/ [Erişim tarihi: 17.12.2017]

4. Rational Drug Use National Action Plan 2014-2017, Ministry of Health, Turkish Medicines and Medical Devices Agency.
PDF Dokümanı [Erişim tarihi: 26.12.2017]

5. Sağlık Meslek Mensupları ile Sağlık Hizmetlerinde Çalışan Diğer Meslek Mensuplarının İş ve Görev Tanımlarına Dair Yönetmelik, Resmi Gazete, 22.05.2014 [Erişim tarihi: 17.12.2017]

6. Ambulans ve Acil Bakım Teknikerleri ile Acil T1p Teknisyenlerinin Çalışma Usul ve Esaslarına Dair Tebiğ, Resmi Gazete 26.03.2009 [Erişim tarihi: 17.12.2017]

7. The Role of Education in the Rational Use of Medicines, SEARO Technical Publication Series No. 45, Distribution: General, WHO, 2006. PDF Dokümanı [Erişim tarihi: 17.12.2017] 
